\title{
Pengaruh Konseling Kognitif Perilaku Terhadap Aktualisasi Diri Siswa
}

\author{
Dede Sri Mulyati* \\ Jurusan Bimbingan dan Konseling Islam, UIN Sunan Gunung Djati, Bandung \\ ${ }^{*}$ Email : dedesrimulyati73@gmail.com
}

\begin{abstract}
ABSTRAK
Tujuan dari penelitian ini adalah, untuk mengetahui pelaksanaan konseling kognitif perilaku di SMA Al-Amanah; tingkat aktualisasi diri siswa di SMA AlAmanah Ciwidey; dan pengaruh penerapan konseling kognitif perilaku terhadap aktualisasi diri siswa kelas XII IPA SMA Al Amanah Ciwidey. Penelitian ini menggunakan pendekatan kuantitatif. Sedangkan, metode penelitian yang digunakan dalam penelitian ini adalah metode deskriptif. Untuk memperoleh data, metode yang dilakukan ialah observasi lapangan, wawancara, dan penyebaran angket. Dalam penelitian ini terdapat hipotesis yaitu terdapat pengaruh antara konseling kognitif perilaku terhadap aktualisasi diri siswa. Dari hasil penyebaran angket pada siswa kelas XII IPA 3 SMA Al-Amanah Ciwidey, dilakukan uji regresi untuk mengetahui pengaruh menggunakan pengujian uji-t signifikansi $0,05(\alpha=5 \%)$. Dari hasil output SPSS Version 20 diperoleh Pv 0,012 artinya $\operatorname{Pv}<\alpha$, atau 0,012 lebih kecil dari nilai 0,05 maka $\mathrm{H}_{0}$ ditolak, ini berarti hipotesis yang diajukan menunjukkan bahwa terdapat pengaruh antara konseling kognitif perilaku dan aktualisasi diri. Sedangkan, untuk mengetahui besarnya pengaruh konseling kognitif perilaku terhadap aktualisasi diri menggunakan koefisien determinasi. Diketahui besarnya pada kolom R Square atau r2=0,100, atau koefisien determinasi dalam penelitian ini bila diubah menjadi persentase adalah $10 \%$, dan sisanya $100 \%-10 \%=90 \%$ di pengaruhi oleh variabel lain selain layanan konseling kognitif perilaku.
\end{abstract}

Kata Kunci : Konseling; kognitif; perilaku; aktualisasi; siswa.

\section{ABSTRACT}

The purpose of this research is, to know the implementation of behavioral cognitive counseling in SMA Al-Amanab; level of self-actualization of students in SMA Al-Amanab Ciwidey; and the influence of the application of behavioral cognitive counseling to self-actualization of grade students of XII SMA AL Amanab Cividey. This study uses a quantitative approach. Meanwhile, research method used in this research is descriptive method. To obtain 


\section{S. Mulyati}

data, the method used is field observation, interview, and questionnaire. In this study there is a bypothesis that there is influence between counseling cognitive behavior to self-actualization of students. From the results of questionnaires dissemination in grade XII IPA 3 SMA AlAmanah Ciwidey students, conducted regression test to determine the effect of using the test- $t$ test of significance $0.05(a=5 \%)$. From result of output of SPSS Version 20 obtained Pv 0.012 mean $\mathrm{Pv}<\mathrm{a}$, or 0,012 smaller than value 0,05 then $\mathrm{HO}$ is rejected, this means bypothesis proposed indicate that there is influence between behavioral cognitive counseling and self actualization. Meanwhile, to know the influence of counseling cognitive behavior toward self-actualization using coefficient of determination. Given the magnitude of $\mathrm{R} S$ quare or $r 2=$ 0,100, or the coefficient of determination in this study when converted into percentage is $10 \%$, and the remaining 100\% - 10\% $=90 \%$ is influenced by other variables besides behavioral counseling services.

Keywords: Counseling; cognitive; behavior; actualization; students.

\section{PENDAHULUAN}

Remaja merupakan tahapan hidup seseorang yang senantiasa dihadapkan dengan berbagai tantangan, karena terdapat berbagai perubahan yang terjadi mulai dari perubahan fisik, biologis, psikologis, dan juga sosial. Ketika seorang remaja tidak mampu mengatasi tantangan tersebut, akan muncul berbagai penyimpangan psikologis, emosional dan perilaku yang merugikan (Gerald, 2011: 6). Dalam masa pencarian identitas, remaja harus menghadapi berbagai tantangan konflik pada dirinya. Konflik muncul antara upaya berprilaku baik didepan orang tuanya, dan menghidari perilaku yang menjadi olok-olokan teman sebayanya. Remaja yang diterima, dicintai dan dihargai oleh keluarga dan teman sebaya umumnya memperoleh kepercayaan diri dan dapat mengembangkan potensi dan tujuan-tujuan positif untuk mencapai tingkat aktualisasi diri (Kozier, 2010 dalam Wijayanti, 2015: 44 ).

Remaja senantiasa berimajinasi dan berambisi tanpa batas dan bercita-cita untuk mencapai prestasi yang gemilang, Menjadi remaja yang mampu mengaktualisasikan diri dengan baik di lingkungan sosial merupakan harapan sebagian besar remaja. Pada anak-anak SMA, beberapa anak berusaha untuk mendapatkan prestasi dalam kegiatan ekstrakurikuler, kegiatan organisasi, bidang olahraga, dan kegiatan-kegiatan sosial (Hurlock, 2002: 11).

Aktualisasi diri sendiri merupakan suatu proses menjadi diri sendiri dengan mengembangkan sifat-sifat serta potensi individu sesuai dengan keunikannya yang ada untuk menjadi kepribadian yang utuh, bebas dari tekanan dari dalam diri maupun dari luar. Kebutuhan aktualisasi diri didorong motif perkembangan yang tidak bersifat hierarkis sebagaimana kebutuhan dasar manusia, meskipun demikian bila kebutuhan ini tidak terpenuhi akan mengakibatkan penyimpanganpenyimpangan, atau penyakit yang bersifat psikologis (Ghofur, 2006: 12). 
Sebagaimana fenomena kenakalan remaja yang sering terjadi di sekolah dan lingkungan sosial lainnya. Kenakalan seringkali dianggap hal yang lumrah dilakukan pada sosok remaja sebagai wujud aktualisasi diri dan eksistensi mereka. Namun apa jadinya jika kenakalan yang remaja ini sudah tidak wajar dan lebih mengarah pada tindakan kriminal. Tentunya hal ini menjadi perhatian, khususnya mereka yang akan berkecimpung dalam dunia pendidikan, yang hendak mempersiapkan generasi penerus bangsa yang cemerlang.

Maslow berpendapat bahwa manusia dimotivasi untuk menjadi segala sesuatu yang dia mampu untuk menjadi itu. Walaupun kebutuhan hidupnya terpenuhi, namun apabila kebutuhan aktualisasi diri tidak terpenuhi, tidak mengembangkan atau tidak mampu menggunakan kemampuan bawaannya secara penuh, maka seseorang akan mengalami kegelisahan, ketidak senangan, atau frustasi (Juntika, 2011: 160).

Monty P. Satiadarma (Oemarjoedi, 2003: 8) mengatakan bahwa penyimpangan perilaku manusia terjadi karena adanya penyimpangan fungsi kognitif. Untuk memberbaiki perilaku manusia yang mengalami penyimpangan tersebut terlebih dahulu harus dilakukan perbaikan terhadap fungsi kognitif manusia. Pernyataan ini menunjukan pentingnya pengaruh aspek kognitif terhadap perilaku manusia. Peran kognitif dalam mempertimbangkan keputusan untuk malakukan tindakan tertentu menjadi fokus perhatian dalam pendekatan cognitive behavior therapy.

Salah satu penyebab seseorang tidak mampu mengaktualisasikan dirinya ialah, karena terdapat perasaan ragu dan takut mengungkapkan potensi diri, sehingga potensinya tidak dapat berkembang. Potensi diri merupakan modal yang perlu diketahui, digali dan dimaksimalkan. Sesungguhnya perubahan hanya bisa terjadi jika kita mengetahui potensi yang ada dalam diri kita kemudian mengarahkannya kepada perilaku yang benar dan terpuji (Fadlymun, 2009).

Boy dan Pine (Depdikbud, 1983:14) menyatakan bahwa tujuan konseling adalah membantu siswa menjadi lebih matang dan lebih mengaktualisasikan dirinya, membantu siswa maju dengan cara yang positif, membantu dalam sosialisasi siswa dengan memanfaatkan sumber-sumber dan potensinya sendiri.

Dari hasil wawancara awal, pada bulan september 2017 dengan guru BK mengenai masalah tingkat aktualisasi diri siswa di SMA Al Amanah Ciwidey, diperoleh keterangan tentang upaya dalam meningkatkan aktualisasi diri:

"Sebagaimana sekolah lainnya, kami sebagai guru BK memberikan layanan bimbingan konseling klasikal. Layanan ini dilaksanakan melalui kegiatan dalam kelas. Tujuannya untuk memberikan informasi kepada siswa berkenaan dengan urusan pelajaran, pengembangan potensi diri, perilaku, 
dan karir. Kegiatan tersebut juga sebagai upaya preventif agar siswa tidak salah langkah dalam mengaktualisasikan dirinya. Meskipun dengan adanya kegiatan ini, masih terdapat beberapa siswa yang belum mampu mengaktualisasikan diri dengan baik, entah itu karena malu, tidak percaya diri, atau siswa mampu mengaktualisasikan diri, namun dengan cara yang negatif, seperti berfikir bahwa dengan merokok, ikut genk motor, pacaran adalah hal yang hebat. Untuk mencegah atau mengatasi penyimpangan seperti itu guru BK memberikan pengarahan dan memperbaiki pola pikir siswa yang dianggap salah, dan mengarahkan siswa agar mampu berfikir dan bertindak positif. Teknik yang biasa dilakukan ialah dengan memberikan informasi tentang akibat dari penyimpangan yang dilakukan siswa dengan menunjukkan bukti atau menceritakan pengalaman orang lain, mengarahjab pikiran siswa yang dianggap salah dan membantu siswa menemukan pola pikir dan perilaku baru yang lebih baik. Teknik tersebut biasa dilakukan dalam setting individu maupun kelompok."

Berdasarkan pengamatan penulis, teknik yang dilakukan guru BK dalam mengarahkan, atau mengembangkan aktualisasi diri siswa ialah konseling kognitif perilaku. Konseling kognitif perilaku adalah suatu pendekatan yang mengkombinasikan teknik kognitif dan perilaku untuk membantu seseorang memperbaiki pola pikir dan perilaku yang merusak diri. Tujuan dari konseling kognitif perilaku yaitu mengajak konseli untuk menentang pikiran dan emosi negatif dengan memperlihatkan bukti-bukti yang berlawanan dengan keyakinan mereka tentang permasalahan yang dihadapi.

Penelitian terdahulu yang dilakukan oleh Ireel, Elita \& Mishbahuddin (2018) mengungkapkan bahwa kecemasan siswa menghadapi ujian menurun setelah diberikan layanan konseling kelompok dengan teknik restrukturisasi kognitif. Selanjutnya, Selvia, Sugiharto \& Samsudi (2017) mengungkapkan bahwa menunjukkan bahwa konseling kelompok teknik cognitive restructuring dan thought stopping efektif untuk mengurangi perilaku bullying siswa. Kemudian penelitian yang dilakukan oleh Padmi (2017) mengungkapkan bahwa terdapat perbedaan yang signifikan pengaruh konseling kognitif behavioral model Aaron Beck dengan strategi managemen diri dan konseling konvensional terhadap self autonomy. Selain itu, Farihah \& Rachman (2017) mengungkapkan bahwa konseling dengan berbagai terapi dalam pendekatan cognitive behavior therapy berbasis Islam dapat membantu menurunkan tingkat kecemasan narapidana. Fatimah \& Muksin (2017) mengungkapkan bahwa anak dapat terlibat dalam kegiatan bimbingan, hal ini sesuai dengan hasil penyebaran angket kepada anak, menunjukan bahwa rasa percaya diri anak saat melakukan latihan terlihat sangat bagus .

Adapun kaitannya dengan aktualisasi diri, Nurhadi (2017) mengungkapkan 
bahwa aktualisasi diri dipengaruhi oleh faktor intern dan ekstern. Kemudian Supriatna (2017) menyebutkan bahwa pada umumnya pencapaian kecakapan pribadi subjek penelitian belum optimal, baik dalam aspek memahami dirinya sendiri, memahami orang lain, maupun dalam berinteraksi sosial secara bermakna.

Berdasarkan pemaparan di atas, peneliti tertarik untuk meneliti lebih lanjut mengenai ada tidaknya Pengarub Konseling Kognitif Perilaku Terbadap Aktualisasi diri Siswa di SMA Al-Amanah Ciwidey. Adapun pertanyaan atau masalah yang diuraikan dalam penelitian ini antara lain 1) bagaimana pelaksanaan Konseling Kognitif Perilaku di SMA Al Amanah Ciwidey?; 2) bagaimana aktualisasi diri siswa kelas XII di SMA Al Amanah Ciwidey?; 3)apakah ada pengaruh penerapan metode konseling kognitif perilaku terhadap aktualisasi diri siswa kelas XII SMA Al Amanah Ciwidey?

Jenis penelitian yang digunakan dalam penelitian ini adalah penelitian kuantitatif dengan pendekatan deskriptif. Metode penelitian kuantitatif dapat diartikan sebagai metode penelitian yang berlandaskan pada filsafat positivisme, digunakan untuk meneliti pada populasi atau sampel tertentu, teknik pengambilan sampel pada umumnya dilakukan secara random, pengumpulan data menggunakan instrumen penelitian, analisis data bersifat kuantitatif statistik dengan tujuan untuk menguji hipotesis yang telah ditetapkan. Penelitian ini menggunakan pendekatan deskriptif dengan tujuan untuk mendeskripsikan objek penelitian ataupun hasil penelitian (Sugiyono, 2013: 13).

\section{LANDASAN TEORITIS}

Penelitian tentang konseling kognitif perilaku pernah diteliti sebelumnya oleh Rika Damayanti dengan judul pengaruh konseling kognitif perilaku dengan teknik restrukturisasi kognitif terhadap Harga diri peserta didik, dengan hasil bahwasannya konseling kognitif perilaku berpengaruh terhadap harga diri peserta didik. Penelitian kedua oleh Septinisa tentang pengaruh konseling kognitif perilaku dalam meningkatkan perilaku belajar peserta didik dengan hasil bahwasannya kegiatan konseling kognitif perilaku dapat meningkatkan perilaku belajar siswa. Penilitian ketiga ialah oleh Nina Maryati dengan judul pengaruh terapi kognitif perilaku terhadap asertif pada remaja, dengan hasil bahwasannya konseling kognitif dapat meningkatkan perilaku asertif pada remaja. Sedangkan penelitian ini akan memaparkan pengaruh konseling kognitif perilaku terhadap aktualisasi diri siswa. Berikut landasan teori tentang konseling kognitif perilaku dan aktualisasi diri.

Konseling kognitif perilaku merupakan sebuah model konseling yang menggabungkan prinsip-prinsip dan metode kognitif dan perilaku dalam sebuah 


\section{S. Mulyati}

pendekatan treathment yang singkat (Corey, 2005: 271). Terapi cognitive behavior efektif dilakukan terhadap klien dengan latar belakang yang berbeda-beda dalam hal pendidikan, penghasilan, usia, dan budaya. Kerjasama yang harmonis antara konselor dan klien memberikan kesempatan pada klien untuk mengekspresikan pemikiran mereka secara bebas namun terarah. Penekanan terapi terhadap metode berfikir positif cenderung lebih mudah diterima klien dan mengarah kepada model terapi yang semi terpusat pada klien (semi client centered) dibandingkan teknik-teknik terapi lain yang terpusat pada terapi lain yang terpusat pada terapis. Klien juga akan lebih dapat menghargai cara terapis therapist centered dalam bersikap aktif dan direktif, karena dilakukan secara halus dan menghargai kebutuhan klien (Persons, B \& Perloff dalam Putranto, 2016: 188).

Konseling kognitif perilaku dapat dilaksanakan secara efektif baik dalam latar individu maupun kelompok. Konseling kelompok kognitif perilaku dapat dilaksanakan dalam dua format kegiatan: kelompok homogen dimana semua anggota kelompok mempunyai masalah yang sama, dan format kelompok terbuka dimana anggota kelompok bergiliran mengungkapkan masalah mana yang ingin dibahas. (Vernon, 2012:4).

Tujuan dari konseling Cognitive Behavior yaitu mengajak konseli untuk menentang pikiran dan emosi yang salah dengan menampilkan bukti-bukti yang bertentangan dengan keyakinan mereka tentang masalah yang dihadapi. Konselor diharapkan mampu menolong konseli untuk mencari keyakinan yang sifatnya dogmatis dalam diri konseli dan secara kuat mencoba menguranginya (Oemarjoedi, 2003:9).

Terdapat metode dasar yang digunakan untuk meng-asses kognisi klien: interview, self- recording, self report inventory, prosedur berpikir suara keras. Setiap metode mendapatkan laporan diri klien dari kognisinya, serta mendapatkan informasi langsung tentang pikiran lainnya (Spiegler \& Guevremont, 2003:305).

Pelaksanaan konseling kognitif perilaku memiliki beberapa tahapan yaitu, 1) menciptakan hubungan yang sangat dekat dan aliansi kerja konselor dan klien, dan menjelaskan dasar pemikiran dari penanganan yang akan diberikan; 2) menilai masalah, mengidentifikasi, mengukur frekuensi, intensitas, dan kelayakan masalah perilaku dan kognisi.; 3) menetapkan target perubahan, yang harus dipilih klien, dan harus jelas, spesifik, dan dapat dicapai; 4) penerapan teknik kognitif-perilaku. Dalam penelitian ini Teknik kognitif yang digunakan adalah penghentian pola pikir dan pengubahan pola pikir. Sedangkan teknik perilaku yang dipakai adalah stimulus dan reinforcement; 5) memonitor perkembangan, dengan menggunakan penilaian terhadap perilaku sasaran; 6) mengakhiri dan merancang program lanjutan untuk menguatkan generalisasi dari apa yang 
didapat. (Tajiri, 2010: 10)

Demikianlah pemaparan tentang konseling kognitif perilaku. Selanjutnya ialah pembahasan tentang aktualisasi diri. Aktualisasi adalah keinginan untuk memperoleh kepuasan dengan dirinya (self fulfilment), untuk menyadari semua potensi dirinya, untuk menjadi apa saja yang ia dapat melakukannya, dan untuk menjadi kreatif dan bebas mencapai puncak prestasi potensinya. (Alwisol, 2009:206)

Kebutuhan aktualisasi diri mencakup pemenuhan diri, sadar akan semua potensi diri, dan keinginan untuk menjadi sekreatif mungkin (Maslow, 1970 dalam Feis \& Feist, 2009: 342). Orang mengaktualisasikan diri dapat mempertahankan harga diri mereka bahkan ketika mereka dimaki, ditolak, dan diremehkan oleh orang lain. Dengan kata lain, orang-orang yang mengaktualisasikan diri tidak bergantung pada pemenuhan kebutuhan cinta maupun kebutuhan akan penghargaan. Mereka menjadi mandiri sejak kebutuhan level rendah yang memberi mereka kehidupan (Feist \& Feist, 2009: 335).

Bentuk pengaktualisasian driri ini berbeda pada setiap orang. Hal ini tidak lain disebabkan dan merupakan cerminan dari adanya perbedaan-perbedaan individual. Bagaimanapun, Maslow mengakui bahwa untuk mencapai taraf aktualisasi diri atau memenuhi kebutuhan akan aktualisasi diri tidaklah mudah, sebab upaya ke arah itu banyak sekali hambatan-hambatan (Maslow dalam Friedman, 2008: 352).

Manusia dikendalikan oleh kekuatan internal yang terutaman berasal dari pikiran yang tidak sadar dirinya (Freud dalam Lawrance, 2011:27). Maslow mengemukakan bahwa keinginan untuk mengaktualisasikan diri kita masingmasing, bahwa motivasi atau dorongan terhadap aktualisasi diri itu adalah bawaan, yang setiap individu mempunyai keinginan inheren, yang dibawa sejak lahir, yaitu untuk berada demi keberadaan itu, berbuat demi untuk perbuatan itu, merasa demi perasaan itu, yaitu beraktualisasi diri (Maslow dalam Bernard, 1990: 126-127).

Yang menjadi hambatan dalam diri untuk mengaktualisasikan diri yakni berupa ketidaktahuan, keraguan, dan bahkan juga rasa takut dari individu untuk mengungkapkan potensi-potensi yang dimilikinya, sehingga potensi itu tetap laten.

Menurut Skinner, kekuatan lingkungan adalah hal yang utama, "seseorang tidak beraksi terhadap dunia, dunia beraksi terhadap dirinya (Lawrance, 2011:27).

Hambatan atas upaya aktualisasi diri itu berasal dari luar atau dari 
masyarakat. Hambatan dari masyarakat ini, selain berupa kecenderungan mendepersonalisasi individu, juga berupa penekanan atau pengekangan sifat, bakat atau potensi-potensi. Aktualisasi diri itu hanya mungkin apabila kondisi lingkungan menunjang. Dan dalam kenyataannya, menurut keyakinan Maslow, tidak ada satu pun lingkungan masyarakat yang sepenuhnya menunjang atas upaya aktualisasi diri warganya, meski tentunya ada beberapa masyarakat yang jauh lebih baik dan menunjang daripada masyarakat yang lainnya (Koeswara, 1991: 126).

Karakteristik orang yang mengaktualisasi diri. Keempat belas nilai tersebut mengindikasikan nilai-nilai universal yang diteima oleh semua orang sebagai kebaikan. Orang yang mengaktualisasikan diri mampu menyerap nilai-nilai tersebut ke dalam dirinya, menyatu dengan dirinya. (Goble, 1987: 92). Berikut merupakan karakteristik orang yang mengaktualisasikan diri: (1) persepsi yang lebih efisien akan kenyataan, (2) penerimaan akan diri, orang lain, dan hal-hal alamiah, (3) spontanitas, kesederhanaan, dan kealamian, 4) berpusat pada masalah, (5) kebutuhan akan privasi, (6) kemandirian, (7) penghargaan selalu baru; 8) pengalaman puncak, (9) gemeinschaftsgefuhl, (10) hubungan interpersonal yang kuat, (11) struktur karakter yang demokratis, (12) rasa jenaka atau humor yang filosofis, (13) kreatifitas, (14) tidak mengikuti enkulturasi (Feist\&feist, 2010: 345-350).

\section{HASIL DAN PEMBAHASAN}

Penelitian ini dilakukan di SMA Al-Amanah Ciwidey. SMA Al-Amanah merupakan sekolah swasta yang berada di Jl.Komplek Masjid Besar Ciwidey RT 004 RW 011 Kelurahan Ciwidey, Kecamatan Ciwidey Kabupaten Bandung 40973 Jawa Barat. Lebih jelasnya SMA Al Amanah berada di belakang Masjid Besar Ciwidey, sebelah TK Budi Mekar, dan KUA Kecamatan Ciwidey. Adapun SMA Al Amanah telah memiliki kampus kedua yang terletak tidak jauh dari kampus utama yaitu di kampong Ciloa desa Ciwidey Kab. Bandung 40973.

SMA Al- Amanah Ciwidey didirikan pada tanggal 22 September 2003 atas dasar musyawarah pengurus Yayasan Al-Amanah Ciwidey. Hingga saat ini jumlah siswa di SMA Al Amanah ialah 898, yaitu kelas X berjumlah 364 siswa, kelas XI berjumlah 287, dan kelas XII berjumlah 247 siswa. SMA Al Amanah diketuai oleh Drs. Agus Hermawan, M.Si.

Berdasarkan hasil penelitian, pelaksanaan konseling kognitif perilaku dilakukan oleh tiga guru bk. KKP dilaksanakan dalam setting individu dan kelompok. Kegiatan konseling kognitif perilaku di SMA Al-Amanah sudah tergolong baik. Begitupula dengan tingkat aktualisasi diri siswa tergolong baik, meskipun pengaruhnya dari adanya kegiatan konseling kognitif perilaku hanya 
$10 \%$.

\section{Pelaksanaan Konseling Kognitif Perilaku}

Layanan bimbingan konseling kognitif perilaku tujuannya untuk memberikan informasi kepada siswa berkenaan dengan urusan pelajaran, pengembangan potensi diri, perilaku, dan karir. Kegiatan tersebut juga sebagai upaya preventif agar siswa tidak salah langkah dalam mengaktualisasikan dirinya. Teknik yang biasa dilakukan ialah dengan memberikan informasi tentang akibat dari penyimpangan yang dilakukan siswa dengan menunjukkan bukti atau menceritakan pengalaman orang lain, mengarahkan pikiran siswa yang dianggap salah dan membantu siswa menemukan pola pikir dan perilaku baru yang lebih baik. Teknik tersebut biasa dilakukan dalam setting individu maupun kelompok.

Berdasarkan analisis penulis, teknik yang dilakukan guru BK dalam mengarahkan, atau mengembangkan aktualisasi diri siswa ialah konseling kognitif perilaku. Konseling kognitif perilaku adalah suatu pendekatan yang mengkombinasikan teknik kognitif dan perilaku untuk membantu seseorang memperbaiki pola pikir dan perilaku yang merusak diri. Tujuan dari konseling kognitif perilaku yaitu mengajak konseli untuk menentang pikiran dan emosi negatif dengan memperlihatkan bukti-bukti yang berlawanan dengan keyakinan mereka tentang permasalahan yang dihadapi. Berdasarkan penelitian bahwa konseling kognitif perilaku memiliki pengaruh terhadap aktualisasi diri siswa. Meskipun pengaruh yang diberikan tidak terlalu signifikan.

Responden yang diambil menggunakan teknik simple random sampling karena pengambilan anggota sampel dan populasi yang dilakukan secara acak tanpa memperhatikan strata yang ada dalam populasi itu. Maka peneliti mengambil 25\% dari jumlah populasi 251 siswa (kelas XII) di SMA Al-Amanah Ciwidey. Berdasarkan perhitungan berikut maka didapat 63 orang yang menjadi responden dalam penelitian ini. Jumlah populasi 251 x $25: 100=62,75$ dibulatkan menjadi 63 siswa.

Peneliti telah mendapatkan data mentah dari hasil angket. Supaya data mentah tersebut dapat diinterpretasikan, maka peneliti mengolahnya secara lebih lanjut dengan rumus untuk menemukan presentasi masing-masing jawaban yang muncul. Berikut hasil rekap data variabel x dan y;

\section{Tabel 1}

Nilai rata-rata persentase Konseling Kognitif Perilaku di SMA Al-Amanah

\begin{tabular}{ll}
\hline No. Pernyataan & Nilai \\
& Persentase \\
\hline
\end{tabular}


1 Guru BK berpartisipasi dalam penyelesaian masalah siswa

$81 \%$

2 Guru BK selalu mengamati kemajuan dalam perubahan

$90 \%$ perilaku siswa

3 Guru BK memahami masalah siswa secara mendalam

$66 \%$

4 Guru BK senantiasa membantu siswa secara bersama-sama

$87 \%$ menguraikan masalah dan memperoleh pemahaman yang lebih jelas tentang permasalahan yang dialami siswa

5 Guru BK senantiasa berupaya menggali setiap pikiran,

$69 \%$ ekspresi, emosi dan tingkah laku yang berhubungan dengan permasalahan siswa

6 Guru BK membandingkan pikiran, ekspresi, emosi dan tingkah laku siswa yang berhubungan dengan permasalahan, dengan norma masyarakat yang berlaku dan kehidupan nyata

7 Guru BK menggunakan teknik-teknik yang mudah diikuti dalam sesi konseling.

8 Guru BK selalu memberi semangat dalam mencari pemikiran-pemikiran yang lebih positif dan masuk akal

9 Guru BK selalu memberikan dukungan kepada siswa untuk merubah cara berfikir yang salah

10 Guru BK melakukan diskusi bersama siswa dalam mengambil kesimpulan dan keputusan

11 Guru BK selalu menceritakan pengalaman yang berhubungan dengan permasalahan siswa.

12 Guru BK mengarahkan siswa dalam melakukan perubahan cara berfikir yang negatif.

13 Guru BK mengajarkan cara berbicara kepada diri sendiri dalam rangka mengoreksi diri.

14 Guru BK melakukan kegiatan konseling atau belajar dengan memperlihatkan gambar, film, internet, dsb.

15 Guru BK selalu mengendalikan proses belajar/konseling $\quad 68 \%$ tanpa mengabaikan kebutuhan siswa

16 Guru BK berusaha membantu siswa merubah pola berfikir siswa tanpa membuat siswa merasa terpaksa

17 Guru BK memberikan layanan konseling tanpa memaksa $79 \%$ pada siswa yang tidak membutuhkan konseling.

18 Guru BK selalu memberikan dukungan semangat demi membuktikan bahwa proses konseling akan memberikan hasil yang efektif dalam mengatasi masalah. 
20 Guru BK selalu meyakinkan bahwa siswa akan memiliki dan perbuatannya yang salah kearah yang positif

21 Guru BK melakukan konseling dengan singkat (5-6 sesi) dengan hasil yang memuaskan

Berdasarkan penelitian melalui penyebaran angket tentang Konseling Kognitif Perilaku yang dilaksanakan pada siswa SMA Al-Amanah Ciwidey kelas XII hasilnya adalah $77 \%$, angka tersebut dalam persentase skala nilai kualifikasi baik. Artinya konseling kognitif perilaku yang dilakukan Guru BK di SMA AlAmanah Ciwidey sudah baik.

Konseling kognitif perilaku dapat dilaksanakan secara efektif baik dalam latar individu maupun kelompok. Konseling kelompok kognitif perilaku dapat dilaksanakan dalam dua format kegiatan: kelompok homogen dimana semua anggota kelompok mempunyai masalah yang sama, dan format kelompok terbuka dimana anggota kelompok bergiliran mengungkapkan masalah mana yang ingin dibahas. (Tajiri, 2012: 4).

\section{Kondisi Aktualisasi Diri Siswa}

Responden yang diambil menggunakan teknik Simple Random Sampling karena pengambilan anggota sampel dan populasi yang dilakukan secara acak tanpa memperhatikan strata yang ada dalam populasi itu. Maka peniliti mengambil sampel $25 \%$ dari kelas XII yang berjumlah 251 yaitu $251 \times 25: 100=$ 62,75 dibulatkan menjadi 63 siswa

Tabel 2

Nilai Rata-rata Aktualisasi Diri Siswa SMA Al-Amanah Ciwidey Kelas XII

\begin{tabular}{lll}
\hline No $\quad$ Pernyataan & $\begin{array}{l}\text { Nilai } \\
\text { Persentase }\end{array}$ \\
$1 \quad \begin{array}{l}\text { Saya mampu mengenali kebohongan, kecurangan, atau kepalsuan } \\
\text { orang lain }\end{array}$ & $70 \%$ \\
$2 \quad \begin{array}{l}\text { Saya berusaha menerima kenyataan meskipun tidak sesuai harapan } \\
\text { nat }\end{array}$ & $74 \%$ \\
\hline
\end{tabular}


3 Saya bersikap sabar dalam menerima kekurangan dan kelebihan diri sendiri

4 Saya bersikap toleransi terhadap kekurangan dan kelebihan orang lain

5 Saya membuka diri terhadap kritikan, saran, ataupun nasehat dari orang lain terhadap dirinya.

6 Saya berperilaku wajar, sederhana dan spontan tanpa berpura-pura dan dilebih-lebihkan

7 Saya berani mengemukakan pendapat meskipun bertentangan dengan lingkungan

8 Saya memusatkan perhatian pada masalah dibandingkan diri sendiri

$9 \quad$ Saya peduli pada masalah yang terjadi diluari diri sendiri

10 Saya lebih memandang tugas adalah sebagai tanggung jawab, atau kewajiban

11 Saya percaya bahwa saya mampu bertahan terhadap segala persoalan yang mengguncang tanpa putus asa

12 Saya percaya bahwa saya mampu melakukan apapun dan kapanpun tanpa dipengaruhi oleh lingkungan (situasi dan kondisi)

13 Saya bersikap menghargai hal-hal yang baik dalam kehidupan

14 Saya bersikap menghargai apa yang dimiliki tanpa mengeluh bosan dengan apa yang dimiliki

15 Saya merasa empati, iba kasih sayang, dan ingin membantu orang lain

16 Saya mampu menjalin hubungan yang baik dengan orang lain

17 Saya menjalin hubungan yang akrab penuh rasa kasih sayang

18 Saya bergaul dan bersikap dengan siapapun meskipun berbeda berdasarkan penggolongan, etis, agama, suku, ras, status sosial, ekonomi, dsb.

19 Saya hanya tertawa pada humor yang tidak mengandung unsur hinaan, ejekkan, merendahkan orang lain

20 Saya melakukan inovasi-inovasi yang spontan, asli, tidak dibatasi lingkungan maupun orang lain

21 Saya meyakini dan mempertahankan pendirian dan keputusan yang $\quad 78 \%$ diambil

22 Saya berasumsi bahwa pendapat orang lain hanya berupa saran 
\begin{tabular}{lll}
\hline 24 & $\begin{array}{l}\text { Saya meyakini keputusan yang saya ambil tanpa dipengaruhi orang } \\
\text { lain }\end{array}$ & $75 \%$ \\
Rata-rata & $80 \%$ \\
\hline
\end{tabular}

Berdasarkan penelitian melalui penyebaran angket tentang aktualisasi diri siswa SMA Al-Amanah Ciwidey kelas XII adalah 80\%, angka tersebut dalam persentase skala nilai kualifikasi baik. Dengan adanya layanan konseling kognitif perilaku sangatlah membantu dan mempengaruhi tingkat aktualisasi diri siswa kelas XII.

Aktualisasi diri tidak hanya berupa ciptaan kreasi atau karya-karya berdasarkan bakat-bakat atau kemampuan-kemampuan khusus. Orang tua, mahasiswa, dosen, sekertaris dan buruh pun bisa mengaktualisasikan dirinya, yakni dengan jalan membuat yang terbaik, atau bekerja sebaik-baiknya sesuai dengan bidannya masing-masing. (Maslow dalam Koeswara, 1992: 125)

\section{Pengaruh Konseling Kognitif Perilaku Terhadap Aktualisasi Diri Siswa}

\section{Uji Validitas}

Dengan menggunakan responden siswa SMA Al-Amanah Ciwidey dan B dengan jumlah responden sebanyak 101 siswa, maka nilai $\mathrm{r}$ tabel dapat diperoleh melalui table $\mathrm{r}$ product moment pearson dengan $\mathrm{df}=\mathrm{n}-2$, sehingga berlaku aturan kriteria uji : Rhitung (Corrected Item-Total Correlation) $>$ Rtabel.

\section{Tabel 3}

\section{Item Total Statistics Variabel X (Konseling Kognitif Perilaku)}

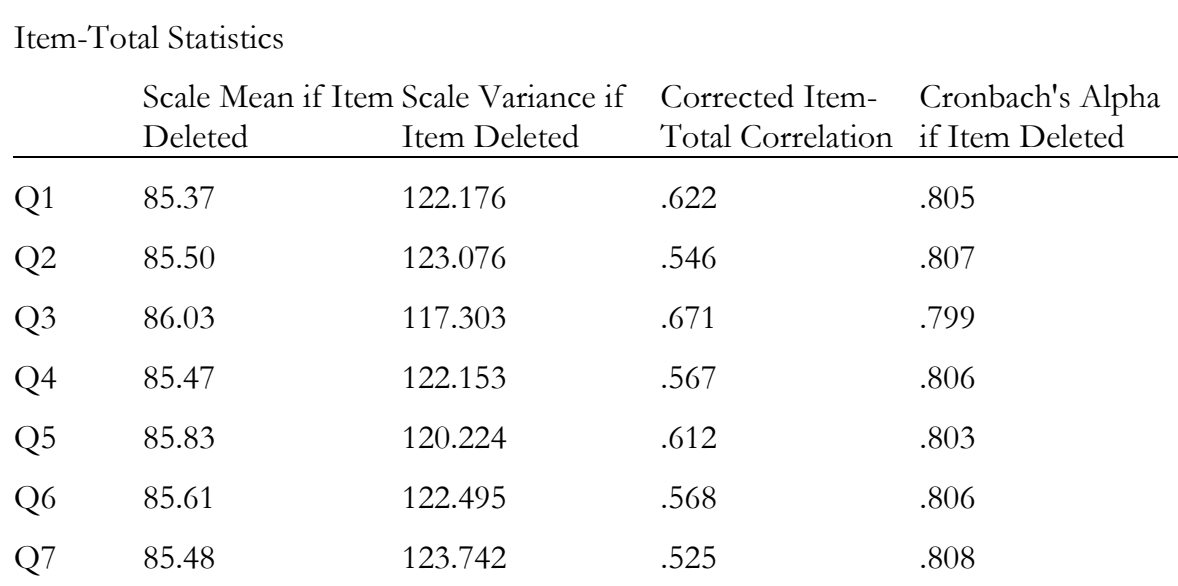


D. S. Mulyati

\begin{tabular}{|c|c|c|c|c|c|}
\hline Q8 & 85.27 & 123.514 & .587 & .807 & $\begin{array}{l}\text { Sumber } \\
\text { Data: }\end{array}$ \\
\hline Q9 & 85.30 & 124.703 & .397 & .812 & Output \\
\hline Q10 & 85.34 & 125.207 & .512 & .810 & $\begin{array}{l}\text { SPSS } \\
\text { Versi 20, }\end{array}$ \\
\hline Q11 & 85.45 & 123.367 & .500 & .808 & 2018 \\
\hline Q12 & 85.73 & 123.318 & .409 & .811 & \\
\hline Q13 & 85.56 & 123.856 & .484 & .809 & Rtabel \\
\hline Q14 & 85.85 & 119.851 & .539 & .805 & yang \\
\hline Q15 & 85.84 & 119.799 & .575 & .804 & $\begin{array}{l}\text { digunak } \\
\text { an = }\end{array}$ \\
\hline Q16 & 85.67 & 123.047 & .618 & .806 & 0,1937 \\
\hline Q17 & 85.47 & 124.918 & .431 & .811 & $\operatorname{dan} \alpha=$ \\
\hline Q18 & 85.34 & 125.089 & .507 & .810 & $5 \%$. \\
\hline Q19 & 85.64 & 122.429 & .637 & .805 & nilai \\
\hline Q20 & 85.37 & 124.215 & .564 & .808 & Rhitung \\
\hline Q21 & 85.94 & 117.467 & .714 & .798 & (Correcte \\
\hline
\end{tabular}

Total Correlation) > Rtabel maka semua item Q1 hingga Q21 dinyatakan Valid.

Tabel 4

Item Total Statistics Variabel Y (Aktualisasi Diri)

Item-Total Statistics

Scale Mean if Item Scale Variance if Corrected Item- Cronbach's Alpha if Deleted Total Correlation Item Deleted

\begin{tabular}{lllll} 
& Deleted & Item Deleted & Total Correlation & Item Deleted \\
\hline Q1 & 100.89 & 72.253 & .296 & .813 \\
Q2 & 100.23 & 72.357 & .349 & .811 \\
Q3 & 100.34 & 71.462 & .448 & .808 \\
Q4 & 100.36 & 72.605 & .425 & .809 \\
Q5 & 100.31 & 72.432 & .401 & .810 \\
Q6 & 100.18 & 72.289 & .401 & .809 \\
Q7 & 101.00 & 70.039 & .449 & .806 \\
Q8 & 100.99 & 70.363 & .334 & .812 \\
Q9 & 100.79 & 68.915 & .514 & .803 \\
Q10 & 100.32 & 72.514 & .329 & .812 \\
Q11 & 100.41 & 69.185 & .568 & .802 \\
\hline
\end{tabular}




\begin{tabular}{|c|c|c|c|c|c|}
\hline $\begin{array}{l}\text { Sumber } \\
\text { Data: }\end{array}$ & Q12 & 100.93 & 69.652 & .492 & .805 \\
\hline Output & Q13 & 100.14 & 71.805 & .411 & .809 \\
\hline $\begin{array}{l}\text { SPSS } \\
\text { Versi 20, }\end{array}$ & Q14 & 100.30 & 71.232 & .487 & .806 \\
\hline 2018 & Q15 & 100.21 & 73.268 & .393 & .811 \\
\hline & Q16 & 100.25 & 73.093 & .346 & .811 \\
\hline $\mathrm{R}$ & Q17 & 100.30 & 71.977 & .441 & .808 \\
\hline tabel & Q18 & 100.15 & 72.910 & .315 & .812 \\
\hline $\begin{array}{l}\text { yang } \\
\text { diguna }\end{array}$ & Q19 & 100.77 & 71.749 & .273 & .815 \\
\hline kan $=$ & Q20 & 100.90 & 71.932 & .388 & .810 \\
\hline 0,1937 & Q21 & 100.47 & 70.761 & .449 & .807 \\
\hline $\begin{array}{l}\text { dan } \alpha \\
=5 \%\end{array}$ & Q22 & 100.69 & 72.491 & .277 & .814 \\
\hline Karena & Q23 & 100.62 & 71.434 & .384 & .809 \\
\hline nilai & Q24 & 100.52 & 72.977 & .266 & .814 \\
\hline
\end{tabular}

\section{Uji Realibilitas}

Dari Uji coba alat ukur (pembagian angket) yang telah dilakukan pada 103 responden (non sampel) dari data yang telah diolah maka mendapatkan hasil seperti dibawah ini:

\section{Variabel X (Konseling Kognitif Perilaku)}

Dalam mengguji realibilitas digunakan uji konsistensi internal dengan menggunakan rumus Alpha Cronbach sebagai berikut:

Uji Realibilitas $=\alpha \geq 0,7$ (maka dikatakan realibel)

Berikut hasil uji reliabilitas 103 responden yaitu:

Tabel 6

\begin{tabular}{|c|c|c|}
\hline & Reliability Statistics & \\
\hline & Cronbach's Alpha & $\mathrm{N}$ of Items \\
\hline & .819 & 21 \\
\hline
\end{tabular}

Sumber Data: Output SPSS Versi 20, 2018 
Dilihat dari tabel Reability Statistic di atas bisa disimpulkan bahwa data termasuk reliable. Karena angka pada Croanbach's Alpha 0,819 lebih besar dari $\alpha=0,05$.

\section{Variabel Y (Aktualisasi Diri Siswa)}

Dalam menguji reliabilitas digunakan uji konsistensi internal dengan menggunakan rumus Alpha Cronbach sebagai berikut:

Uji Realibilitas $=\alpha \geq 0,7$ (maka dikatakan realibel)

Berikut hasil uji reliabilitas 103 responden yaitu:

Tabel 7

Reliability Statistics

Cronbach's Alpha $\mathrm{N}$ of Items

$.817 \quad 24$

$$
\alpha>0,7=0,817>0,7
$$

Sumber Data: Output SPSS Versi 20, 2018

Dilihat dari tabel Reability Statistic di atas bisa disimpulkan bahwa data termasuk reliable. Karena angka pada Croanbach's Alpha 0,817 lebih besar dari $\alpha=0,05$.

\section{Uji Normalitas}

Dalam uji normalitas ini peniliti menggunakan SPSS 20 pengujian dilakukan untuk mengetahui suatu data berdistribusi normal atau tidak dapat dilihat berdasarkan kriteria Asmp Sign (2-tailed) atau Pvalue dan $\alpha$, dengan $\alpha$ adalah sebesal 5\% atau 0,05 , dengan kriteria jika Pvalue $\geq \alpha$ maka data dinyatakan berdistribusi normal dan sebaliknya jika $\mathrm{P}$ value $\leq 0,05$ maka data dinyatakan berdistribusi tidak normal. Adapun hipotesis yang dijadikan pada uji normalitas sebagai berikut:

$$
\begin{aligned}
& \mathrm{H}_{0}=\text { Data berasal dari populasi yang berdistribusi normal } \\
& \mathrm{H}_{1}=\text { data tidak berasal dari populasi yang berdistribusi normal }
\end{aligned}
$$

\section{Tabel 8}




\begin{tabular}{lcccccc} 
& \multicolumn{2}{l}{ Kolmogorov-Smirnova } & \multicolumn{2}{c}{ Shapiro-Wilk } & \\
& Statistic & Df & & Statistic & Df & Sig. \\
\hline $\begin{array}{l}\text { Konseling Kognitif } \\
\begin{array}{l}\text { Perilaku } \\
\text { Aktualisasi Diri }\end{array}\end{array}$ & .091 & 63 & $.200^{*}$ & .985 & 63 & .634 \\
\hline
\end{tabular}

*. This is a lower bound of the true significance.

a. Lilliefors Significance Correction

Sumber Data: Output SPSS Versi 20, 2018

Pengujian normalitas dalam penelitian ini menggunakan Shapiro Wilk, karena banyaknya data lebih dari 30. (Nazir, 2003).

Hipotesis:

Dalam uji Shapiro-Wilk ini diambil taraf signifikasin $(\alpha)$ sebesar 0,05 dengan kriteria pengujian sebagai berikut:

Signifikasi yang diperoleh $>\alpha$, maka $\mathrm{H} 0$ diterima

Signifikasi yang diperoleh $<\alpha$, maka $\mathrm{H} 0$ ditolak

Berdasarkan Tabel Test of Normality terlihatkan bahwa:

Nilai Sig variabel $x$ (Konseling Kognitif Perilaku) adalah 0,634. Karena $0,634>\alpha$ maka $\mathrm{H}_{0}$ di terima. Dengan demikian data pada variabel $\mathrm{x}$ berasal dari populasi yang berdistribusi normal.

Nilai Sig variabel y (Aktualisasi Diri) adalah 0,688. Karena 0,688 $>\alpha$ maka $\mathrm{H} 0$ di terima. Dengan demikian data pada variabel $\mathrm{x}$ berasal dari populasi yang berdistribusi normal. normal.

Jadi kedua variabel tersebut berasal dari populasi yang berdistribusi

\section{Uji Korelasi}

Uji korelasi product moment disebut juga korelasi Pearson yang digunakan untuk menjelaskan kekuatan dan arah hubungan antara dua variabel dengan data berdistribusi normal. Dengan uji korelasi product momen ini peneliti akan 
D. S. Mulyati

mengetahui sejauh mana pengaruh antara Konseling Kognitif Perilaku dan Aktualisasi Diri dikalangan siswa.

Hipotesis

$\mathrm{H}_{0}: \varrho=0 \quad \rightarrow$ Tidak terdapat pengaruh antara konseling kognitif perilaku dan aktualisasi diri

$\mathrm{H}_{1}: \varrho \neq 0 \rightarrow$ Terdapat pengaruh antara konseling kognitif dan aktualisasi

Penelitian ini menggunakan taraf signifikan yang digunakan 5\%

Kriteria Uji

$\begin{array}{ll}\mathrm{Pv}_{\mathrm{V}} \geq \alpha & \rightarrow \mathrm{H}_{0} \text { diterima } \\ \mathrm{Pv}_{\mathrm{v}} \leq \alpha & \rightarrow \mathrm{H}_{0} \text { ditolak }\end{array}$

Tabel 9

\begin{tabular}{llll}
\hline & & $\begin{array}{l}\text { Konseling } \\
\text { Kognitif Perilaku }\end{array}$ & Aktualisasi Diri \\
\hline \multirow{2}{*}{ Konseling Kognitif Perilaku } & Pearson Correlation & 1 & $.316^{* *}$ \\
& Sig. (1-tailed) & & .006 \\
& $\mathrm{~N}$ & 63 & 63 \\
& Pearson Correlation & $.316^{* *}$ & 1 \\
Aktualisasi Diri & Sig. (1-tailed) & .006 & \\
& $\mathrm{~N}$ & 63 & 63 \\
\hline
\end{tabular}

Correlations

Sumber Data: Output SPSS Versi 20, 2018

Dari hasil output SPSS Versi 20 menunjukan bahwa Pvalue Sig. (1-Tailed) sebesar 0,006. Jika dibandingkan dengan taraf 5\% =0,05 dengan persamaan Pvalue $(0,006) \leq \alpha(0,05)$ maka $\mathrm{H}_{0}$ ditolak. Dengan demikian dapat disimpulkan bahwa terdapat hubungan antara Konseling Kognitif Perilaku dengan Aktualisasi diri siswa.

Pada tabel correlation di atas terlihat bahwa $\mathrm{r}=0,316$. Maka dapat disimpulkan bahwa konseling kognitif perilaku dengan aktualisasi diri siswa memiliki hubungan yang rendah, karena posisi angka nilai 0,316 berada di antara 
interval 0,21-0,40. Dapat dilihat pada tabel dibawah ini:

Tabel 10

Tabel Nilai Korelasi

\begin{tabular}{ll}
\hline $\mathrm{R}$ & Interpretasi \\
\hline 0 & Tidak berkorelasi \\
$0,01-0,20$ & Sangat Rendah \\
$0,21-0,40$ & Rendah \\
$0,41-0,60$ & Agak Rendah \\
$0,61-0,80$ & Cukup \\
$0,81-0,99$ & Tinggi \\
1 & Sangat Tinggi \\
\hline
\end{tabular}

(Sugiyono, 2012:184)

\section{Uji Regresi Sederhana (Uji t)}

Uji regresi sederhana (uji t) digunakan untuk mengetahui apakah variabel indepen (X) yang dalam penilitian ini adalah Konseling Kogntif Perilaku berpengaruh signifikan terhadap variabel (Y) atau aktualisasi diri siswa. Pengujian menggunakan taraf signifikan 0,05, dengan kriteria uji apabila $\mathrm{H}_{0}$ diterima mengartikan bahwa variabel bebas tidak berpengaruh secara keseluruhan terhadap variabel terikat. Sedangkan jika H1 diterima maka variabel bebas berpangaruh keseluruhan terhadap variabel terikat.

\section{Hipotesis}

$\mathrm{H}_{0} \quad=$ Tidak terdapat pengaruh konseling kognitif perilaku layanan Konseling kognitif perilaku terhadap aktualisasi diri siswa

$\mathrm{H}_{1} \quad=$ Terdapat pengaruh konseling kognitif perilaku terhadap aktualisasi diri siswa

Kriteria uji :

$$
\begin{array}{ll}
\mathrm{Pv}_{\mathrm{v}}>\alpha & =\mathrm{H}_{0} \text { diterima } \\
\mathrm{Pv}<\alpha & =\mathrm{H}_{0} \text { ditolak }
\end{array}
$$

Hasil uji t dengan menggunakan SPSS versi 20 sebagai berikut

$$
\text { Tabel } 11
$$

\section{Coefficientsa}


D. S. Mulyati

\begin{tabular}{|c|c|c|c|c|c|c|}
\hline \multirow[t]{2}{*}{ Model } & & \multicolumn{2}{|c|}{ Unstandardized Coefficients } & \multirow{2}{*}{$\begin{array}{l}\text { Standardized } \\
\text { Coefficients } \\
\text { Beta }\end{array}$} & \multirow[t]{2}{*}{$\mathrm{t}$} & \multirow[t]{2}{*}{ Sig. } \\
\hline & & $\mathrm{B}$ & Std. Error & & & \\
\hline \multirow{2}{*}{1} & (Constant) & 73.668 & 11.332 & & 6.501 & .000 \\
\hline & Konseling Kognitif Perilaku & .350 & .135 & .316 & 2.600 & .012 \\
\hline
\end{tabular}

Dependent Variable: Aktualisasi Diri

Sumber Data: Output SPSS Versi 20, 2018

Dari tabel di atas menunkkan bahwa $\mathrm{Pv}(0,012)$, artinya lebih kecil dari $\alpha$, atau 0,012 lebih kecil bila dibandingkan dengan nilai 0,05 , maka $\mathrm{H}_{0}$ ditolak, ini berarti hipotesis yang diajukan menunjukkan bahwa terdapat pengaruh antara konseling konitif perilaku terhadap peningkatan aktualisasi diri.

\section{Koefisien determinasi}

Koefisien determinasi digunakan untuk mengetahui besarnya pengaruh antara variabel $\mathrm{X}$ dan $\mathrm{Y}$, atau besarnya pengaruh konseling kognitif perilaku terhadap aktualisasi diri. Hasill ini dapat dilihat dari perhitungannya dengan menggunakan SPSS versi 20 sebagai berikut:

Tabel 12

\section{Koefisien Determinasi}

\begin{tabular}{llll}
\hline \multicolumn{4}{c}{ Model Summary } \\
Model & $\mathrm{R}$ & R Square & Adjusted R Square Std. Error of the \\
& & & \multicolumn{2}{c}{\begin{tabular}{c} 
Estimate \\
\hline 1
\end{tabular}} & $.316 \mathrm{a}$ & .100 & .085 & 7.924 \\
\hline
\end{tabular}

a. Predictors: (Constant), Konseling Kognitif Perilaku

Dependent Variable: Aktualisasi Diri

Sumber Data: Output SPSS Versi 20, 2018

Dari tabel di atas dapat diketahui besarnya pengaruh pada kolom R Square atau $\mathrm{r} 2=0,100$, atau koefisien determinasi dalam penelitian ini bila diubah menjadi persantase adalah $10 \%$, dan sisanya $100 \%-10 \%=90 \%$ di pengaruhi oleh variabel lain selain layanan konseling kognitif perilaku, variabel lain bisa 
berupa faktor internal ataupun eksternal dari individu itu sendiri seperti gender, lingkungan, tingkat pendidikan, dan sebagainya.

\section{Uji linearitas}

Untuk melihat linearitas regresi, dalam penelitian ini menggunakan uji $\mathrm{F}$ dengan ketentuan jika Fhitung lebih kecil dari F tabel, $\alpha=0,05$ dinyatakan linear dan 0,05 dinyatakan linier dan jika fhitung lebih besar dari Ftabel pada taraf signifikan lebih kecil dari probabilitas 0,05 dinyatakan linier, danjika nilai signifikan lebih besar dari probabilitas 0,05 dinyatakan tidak linear

Hipotesis:

$$
\begin{aligned}
& \mathrm{H}_{0} \quad=\text { model regresi tidak linier } \\
& \mathrm{H}_{1} \quad=\text { model regresi linier } \\
& \text { Taraf signifikan } \alpha=0,05 \\
& \text { Kriteria } \mathrm{Uji} \\
& \mathrm{Pv}>\alpha \rightarrow \mathrm{H}_{0} \text { diterima } \\
& \mathrm{Pv} \leq \alpha \rightarrow \mathrm{H}_{0} \text { ditolak }
\end{aligned}
$$

Hasil uji linearitas dengan menggunakan SPSS versi 20 adalah :

\section{Tabel 13}

ANOVA

\begin{tabular}{lllllll}
\hline \multicolumn{2}{c}{ Model } & Sum of Squares & Df & Mean Square & F & Sig. \\
& Regression & 424.483 & 1 & 424.483 & 6.760 & $.012 \mathrm{~b}$ \\
$1 \quad$ Residual & 3830.501 & 61 & 62.795 & & \\
& Total & 4254.984 & 62 & & &
\end{tabular}

Sumber Data: Output SPSS Versi 20, 2018

Dari tabel di atas diketahui $\mathrm{P}_{\mathrm{v}}$ pada kolom Sig 0,012, karena $\mathrm{P}_{\mathrm{v}}<0,05$ yaitu $0,012<0,05$, maka $\mathrm{H}_{0}$ di tolak sehingga variabel antara layanan konseling kognitif perilaku terhadap aktualisasi diri terdapat hubungan linier.

\section{Kesimpulan}

Berdasarkan hasil analisis data telah diketahui bahwa adanya pengaruh antara layanan konseling kognitif terhadap aktualisasi diri siswa, meskipun pengaruh yang ditimbulkan tidaklah signifikan, namun dari hasil penelitian ini menunjukan 
adanya hubungan positif antara layananan konseling kognitif perilaku terhadap aktualisasi diri siswa.

Berdasarkan data yang peneliti dapatkan setelah melakukan wawancara bersama guru BK, yaitu Pak Asep Suhendar, S.Kom., terdapat beberapa kegiatan konseling yang dilakukan di SMA Al-Amanah, yakni konseling klasikal, individu, dan kelompok. Dalam tiga kegiatan tersebut dilakukan dengan berbagai metode/pendekatan, salah satunya ialah konseling konitif perilaku. Media yang sering kali digunakan dalam sesi konseling ialah laptop, whiteboard, projector, speaker, dan Buku modul BK. Kegitatan konseling dilakukan oleh Asep Suhendar, S.Tr.Kom, Nurhasanah, S.Pd, Asep Karmana, S.Pd.

Berikut pelaksanaan konseling kognitif perilaku yang dilakukan di jam pelajaran secara berkelompok, didapatkan peneliti melalui wawancara dan lembar RPL (Rencana Pelaksanaan Layanan) dari Guru BK SMA Al-Amanah Ciwidey :

\section{Tahapan Konseling Kognitif Perilaku}

Langkah pertama ialah pendahuluan berupa pembukaan dengan salam dan sapa. Sebagaimana Kuhnel dan Liberman, (1986), bahwa langkah awal dalam melakukan pendekatan konseling kognitif perilaku ialah menciptakan hubungan yang sangat dekat antara konselor dan klien, dan menjelaskan dasar pemikiran dari penanganan yang akan diberikan. Dalam langkah ini konselor juga dapat menetapkan target perubahan sesuai yang diinginkan oleh siswa, secara jelas, spesifik dan dapat dicapai (John McLeod, 2006:157)

Selanjutnya ialah siswa mendengarkan dan memperhatikan penjelasan konselor tentang materi yang disampaikan. Dalam tahapan ini, konselor mulai melakukan penerapan teknik konseling kognitif perilaku. (John McLeod, 2006:157)

Terakhir, konselor mengadakan evaluasi terhadap peserta didiknya tentang materi yang telah di sampaikan. Sebagaimana dalam Pelaksanaan konseling kognitif-perilaku menurut Kuhnel dan Liberman,, bahwa konselor memonitor perkembangan, dengan menggunakan penilaian berjalan terhadap perilaku sasaran. Langkah terakhir dalam Pelaksanaan konseling kognitif perilaku, konselor mengakhiri dan merancang program lanjutan untuk menguatkan generalisasi dari apa yang didapat (John McLeod, 2006:157).

\section{Metode}

Metode yang digunakan oleh guru BK SMA Al Amanah dalam melakukan layanan konseling ialah metode ekspositori. Metode ekspositori adalah metode pembelajaran yang digunakan dengan memberikan keterangan terlebih dahulu definisi, prinsip dan konsep materi konseling yang akan disampaikan, serta 
memberikan contoh-contoh latihan pemecaan masalah dalam bentuk ceramah, demonstrasi, tanya jawab dan penugasan.

\section{Materi}

Materi yang disampaikan dalam meningkatkan aktualisasi diri siswa dengan konseling kognitif perilaku adalah potensi dasar dan motif serta motivasi. Kebutuhan aktualisasi diri mencakup pemenuhan diri, sadar akan semua potensi diri, dan keinginan untuk menjadi sekreatif mungkin (Maslow, 1970 dalam Feis \& Feist, 2009: 342). Penting juga bagi siswa untuk mampu memahami motif dan motivasi yang nantinya akan menjadi pendorong siswa dalam mengoptimalkan potensi diri dan mencapai puncak prestasi. Sebagaimana menurut Goldstein dalam Suryabrata (2006:326). Aktualisasi diri adalah motif pokok yang mendorong tingkah laku individu (organisme).

Berikut adalah tabel pencapaian kompetensi yang menjadi indikator pemahaman siswa mengenai materi potensi dasar:

Menurut Pak Asep Suhendar bahwasannya kegiatan konseling kognitif perilaku sudah 75\% mencapai apa yang sudah diprogramkan dalam kegiatan BK Kognitif, hal ini menunjukan bahwa kegiatan tersebut akan terus berjalan dan berkesinambungan mengingat setiap tahun para siswa membutuhkan kriteria Bimbingan yang berbeda-beda.

Berdasarkan wawancara dengan Nenden Gita, salah satu siswi kelas XII IPA 1 SMA Al Amanah Ciwidey, bahwasnnya kegiatan konseling bersama guru BK SMA Al Amanah Ciwidey, yaitu Pa Asep Suhendar sangat bermanfaat dan senantiasa memberikan pencerahan kepada siswa. Meskipun Nenden tidak mengetahui metode konseling yang digunakan, namun setiap melakukan sesi konseling di kelas secara kelompok ataupun perorangan di ruang BK, Nenden menilai bahwa sesi konseling yang dilakukan cukup baik dan menarik. Bahkan jam pelajaran konseling senantiasa di tunggu-tunggu para siswa. Karena dengan adanya layanan konseling, para siswa bisa mengatasi kebingungannya dalam mengatasi kesulitan belajar, kesulitan bergaul, dan kesulitas mengembangkan potensi diri. Untuk mengetahui pengaruh konseling kognitif perilaku terhadap aktualisasi diri siswa di SMA Al Amanah Ciwidey persentase jawaban terhadap pertanyaan dirangkum dalam bahasan sebagai berikut:

Bertepatan pada hari Sabtu, Januari 2018, peneliti mengambil 63 siswa dari kelas XII yang pernah mengikuti kegiatan konseling kognitif perilaku sebagai sampel dalam mengklasifikasi konseling kognitif perilaku dan aktualisasi diri siswa. Untuk variabel X (Konseling Kognitif Perilaku) yang diadakan di SMA Al Amanah dapat dilihat dari 7 indikator yang di urai menjadi 21 pertanyaan dengan skor tertinggi 5 dan skor terendah 1 untuk masing-masing item pertanyaan. 
Tabel 3

\section{Persentase Variabel X (Konseling Kognitif Perilaku)}

Untuk variabel Y (Aktualisasi Diri) siswa SMA Al-Amanah ini dapat dilihat dari 14 indikator. 14 indikator tersebut diungkap melalui skala likert dengan jumlah pertanyaan sebanyak 24 buah dengan skor tertinggi 5 dan skor terendah 1 untuk masing-masing item.

Tabel 4

Persentase Variabel Y (Aktualisasi Diri)

\begin{tabular}{|c|c|c|c|}
\hline No & Mandidator lihat realitas secara & 72 & Jumlah $(\%)$ \\
\hline 1 & lebiheftrsisfan partisipasi dan peng & rtian yang lebih besar & 81 \\
\hline 2 & Pekepaffalkonseliadap diri sendiri & 78,7 & \\
\hline 2 & daperfeng dninapangdanefodalam ter & adap pikiran, emosi & 72 \\
\hline 3 & Spdantaningakakelakederhaan dan & 75 & \\
\hline 3 & kewaikrann memperbaiki pola pemik & Iran yang negative & 80 \\
\hline 4 & 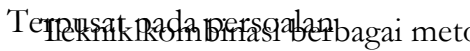 & de $e^{3}$ lan model belajar & 75 \\
\hline 5 & Otsreatifi, kemandirian terhadap & 74 & \\
\hline 5 & 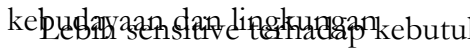 & an konseli & 73 \\
\hline 8 & PeBoharoanakaqusetaly & 83 pikir yang baru dapat & 79 \\
\hline 7 & $\begin{array}{l}\text { Kemendalerikan lachidupan dan fun } \\
\text { baik. }\end{array}$ & sispribadi yang lebih & \\
\hline $\begin{array}{l}8 \\
7 \\
\end{array}$ & $\begin{array}{l}\text { Hubungan interpersonal } \\
\text { Sesi terapi yang fleksibel }\end{array}$ & 81,5 & 66 \\
\hline 9 & Demokratis & 86 & \\
\hline 10 & $\begin{array}{l}\text { Rasa humor yang bermakna dan } \\
\text { etis }\end{array}$ & 76 & \\
\hline 11 & Kreativitas & 69 & \\
\hline 12 & Independensi & 76 & \\
\hline 13 & Pengalaman puncak & 74 & \\
\hline 14 & Kebutuhan akan privasi & 75 & \\
\hline
\end{tabular}

Untuk mengetahui regresi (pengaruh) menggunakan pengujian signifikansi $0,05(\alpha=5 \%)$. Langkah pertama harus menguji terlebih dahulu uji regresi sederhana dengan mengambil angka pada kolom unstandardized coefficients yang dilihat dari kolom sig/signifikasi. Dari hasil output SPSS diperoleh Pv 0,012 artinya $\mathrm{Pv}<\alpha$, atau 0,012 lebih kecil dibandingkan dengan nilai 0,05 maka H0 ditolak, ini berarti hipotesis yang diajukan menunjukkan bahwa terdapat 
pengaruh antara konseling kognitif perilaku dan aktualisasi diri.

Berdasarkan hasil analisis data telah diketahui bahwa adanya pengaruh antara layanan konseling kognitif terhadap aktualisasi diri siswa, meskipun pengaruh yang ditimbulkan tidaklah signifikan, namun dari hasil penelitian ini menunjukan adanya hubungan positif antara layananan ${ }_{\text {konseling }}$ kognitif perilaku terhadap aktualisasi diri siswa.

\section{PENUTUP}

Berdasarkan hasil pengumpulan dan analisis data, bahwa pelaksanaan konseling kognitif perilaku di SMA Al Amanah Ciwidey sudah tergolong baik. Meskipun dari hasil uji koefisien determinasi (uji besar pengaruh) bahwa konseling kognitif perilaku pada aktualisasi diri memiliki pengaruh yang tergolong rendah, namun bagaimanapun terdapat pengaruh positif dari adanya kegiatan konseling kognitif perilaku terhadap aktualisasi diri meskipun hanya 10\%, dan 90\% didapatkan dari faktor lain. Hal ini bisa jadi dipengaruhi oleh sesi konseling di SMA Al Amanah sangat terbatas, sehingga untuk melakukannya di kelas menjadi kurang maksimal, dan apabila dilakukan di luar kelas tidak semua anak bisa mendapatkan layanan konseling. Sehingga diharapkan agar jam pelajaran bimbingan konseling diperpanjang, demi optimalnya layanan konseling yang diberikan. Namun bagaimanapun, kegiatan konseling kognitif perilaku di SMA Al Amanah Ciwidey sudah sangat baik. Begitu pula dengan tingkat aktualisasi diri siswa SMA Al-Amanah Ciwidey termasuk kategori baik.

Melalui penelitian ini diharapkan dapat membantu siswa untuk mempertahankan pencapaian aktualisasi diri mereka, dan tidak menutup kemungkinan untuk meningkatkan lagi tingkat aktualisasi diri. Tentu saja aktualisasi diri yang dilakukan ialah dengan cara yang positif seperti mengaktualisasikan diri dengan menggapai berbagai prestasi akademik maupun non akademik. Bukan dengan unjuk diri dengan perbuatan yang menyimpang hanya untuk sekedar diakui orang lain.

Berdasarkan hasil penelitian bahwa konseling kognitif perilaku berpengaruh terhadap aktualisasi diri siswa. Untuk penelitian selanjutnya, diharapkan dapat melakukan penelitian lanjutan dengan lebih baik. Mengingat, masih banyak hal yang masih perlu dikembangkan dari penelitian ini. Seperti halnya pembuatan instrument penelitian, penulis menyadari bahwasannya instrument yang digunakan masih jauh dari kata sempurna. Maka diharapkan bagi peneliti selanjutnya dapat mengembangkan instrument menjadi lebih baik lagi. 


\section{DAFTAR PUSTAKA}

Agini, M. (2004). Metodologi Penelitian Pendidikan. Jakarta: Rineka Cipta.

Alwisol. (2005). Psikologi Kepribadian (edisi Revisi). Malang: UMM Press.

Corey, G. (2010). Theory \& Practice of Group Counseling, Eighth Edition. California: Brooks/Cole

Corey, G.(2005). Teori dan Praktik Konseling \& Psikoterapi. Bandung: Refika Aditama.

Damayanti, R. (2016). Pengaruh Konseling Kognitif Perilaku Dengan Teknik Restrukturisasi Kognitif Terhadap Harga Diri Peserta Didik Kelas VIII Di Mts N 2 Bandar Lampung. Skripsi, Fakultas Dakwah, IAIN Raden Intan, Lampung. Di akses _ _ 2016, dari https://ejournal.radenintan.ac.id/index.php/konseli.

Farihah, M., \& Rachman, I. (2017). Pendekatan Cognitive Behavior Therapy Berbasis Islam untuk Mengatasi Kecemasan Sosial Narapidana dalam HISB AH: Jurnal Bimbingan Konseling dan Dakwah Islam 14(1) 62-76.

Fatimah, I., \& Muksin, U. (2017). Peningkatan Rasa Percaya Diri Anak Yatim dan Dhuafa melalui Bimbingan Konseling Islam dalam Irsyad: Jurnal Bimbingan, Penyuluhan, Konseling, dan Psikoterapi Islam 5(1) 99-122.

Feist, J \& Feist, J. (2010). Teori Kepribadian (Theories of Personality) (Edisi 7). Jakarta: Salemba Humanika.

Ghofur, O. (2006). Konsep Aktualisasi Diri Abraham. H. Maslow Dan Korelasinya Dalam Membentuk Kepribadian (Analisis Bimbingan Dan Konseling Islam. Skripsi, Fakultas Dakwah, Institut Agama Islaam Negeri Walisongo Semarang. Di Akses 29 Desember 2009, dari https://Anzdoc.Com/Konsep-AktualisasiDiri-Abraham-H-Maslow-Dan-Korelasinya-Dal.Htm.

Goble, F. (1987). Mazhab Ketiga, Psikologi Humanistik Abraham Maslow. Yogyakarta: Kanisius.

Hackney \& Cormier. (2009). Professional Counselor, The: A Process Guide to Helping, 6th Edition. Sherry Cormier, West Virginia University

Hurlock, E.B. (2002). Psikologi Perkembangan: Suatu Pendekatan Sepanjang Rentang Kehidupan. (Terjemahan oleh Tjandrasa, M). Jakarta: Erlangga.

Ireel, A.M., Elita, Y., \& Mishbahuddin, A. (2018). Efektivitas Layanan Konseling Kelompok Teknik Restrukturisasi Kognitif untuk Mereduksi Kecemasan Menghadapi Ujian Siswa Kelas VII SMPN 22 Kota Bengkulu dalam Consilia: Jurnal Ilmiah Bimbingan dan Konseling 1(2) 1-10.

Koeswara. 1991. Teori-teori kepribadian (psikoanalisis, behaviorisme, bumanistic). Bandung: PT Eresco

Maryati, N. (2015). Pengaruh Terapi Kognitif Perilaku Terhadap Perilaku Asertif Pada Remaja. Skripsi. Fakultas Psikologi, UIN Sunan Kalijaga Yogyakarta. Di Akses 2015, dari http:// Ii, B. A. B., \& Remaja, A. A. D. (2015). 
No Title, 8-27.

McLeod, J. 2003. Pengantar Konseling Teori Dan Studi Kasus. Jakarta: Kencana Prenada Media Group.

Nurhadi, N. (2018). Pengembangan Aktualisasi Diri Peserta Didik dalam Meningkatkan Mutu Lulusan di Pondok Pesantren Aliman Putra Ponorogo dalam Muslim Heritage 2(2) 317-338.

Oemarjoedi, A. K.(2003). Pendekatan Cognitive Behavior dalam Psikoterapi. Jakarta: Kreatif Media.

Padmi, N. M. D. (2017). Pengaruh Konseling Kognitif Behavioral Model Aaron Beck dengan Strategi Manajemen Diri terhadap Self Autonomy ditinjau dari Urutan Kelahiran Siswa melalui Lesson Study dalam Jurnal Ilmiah Pendidikan dan Pembelajaran 1(2) 164-175.

Putranto, A. (2016). Aplikasi congnitive behavior dan behavior activation dalam intervensi klinis. Jakarta: Grafindo Books Media.

Selvia, F., Sugiharto, D. Y. P., Samsudi, S. (2017) Teknik Cognitive Restructuring dan Thought Stopping dalam Konseling Kelompok untuk Mengurangi Perilaku Bullying Siswa dalam JUBK 6(1) 20-27.

Septinisa. (2017). Pelaksanaan Pendekatan Konselig Kognitif Perilaku Dalam Meningkatkan Perilaku Belajar Siswa Smp Negeri 11 Bandar Lampung. Lampung: Iain Lampung. Skripsi, Fakultas Tarbiyah dan Keguruan, Institut Agama Islam Negeri (IAIN) Raden Intan Lampung. Di Akses dari http:/ / repository.radenintan.ac.id

Spiegler, M.D \& David C. (2009). Contemporary Behavior Therapy. USA: Thompson Wodsworth.

Sugiyono. (2013). Metode Penelitian Kuantitatif, Kualitatif dan R๘D. Bandung: Alfabeta.

Supriatna, M. (2017). Efektivitas model konseling aktualisasi diri untuk mengembangkan kecakapan pribadi dalam Jurnal Psikologi Pendidikan \& Konseling 3(1) 1-8.

Tajiri, H. (2010). Dakwah dan Pengembangan Kendali Diri: Upaya Antisipasi Kecenderungan Seks Bebas Remaja dalam Ilmu Dakwah: Academic Journal for Homiletic Studies, Universitas Negeri Sunan Gunung Djati Bandung, 4(15), 10.

Wijayanti, R. (2015). Asuban Keperawatan Gerontik. Yogyakarta: CV. Andi Offset. 
D. S. Mulyati 